\title{
Organic carbon stocks in Mediterranean soil types under different land uses (Southern Spain)
}

\author{
M. Muñoz-Rojas ${ }^{1,2, *}$, A. Jordán ${ }^{2}$, L. M. Zavala ${ }^{2}$, D. De la Rosa ${ }^{3}$, S. K. Abd-Elmabod ${ }^{3,4}$, and M. Anaya-Romero ${ }^{1}$ \\ ${ }^{1}$ Evenor-Tech, CSIC Spin-off, Instituto de Recursos Naturales y Agrobiología de Sevilla (CSIC), Seville, Spain \\ ${ }^{2}$ MED_Soil Research Group. Dpto. de Cristalografía, Mineralogía y Química Agrícola, Facultad de Química \\ (Universidad de Sevilla), Seville, Spain \\ ${ }^{3}$ Instituto de Recursos Naturales y Agrobiología de Sevilla (CSIC), Seville, Spain \\ ${ }^{4}$ Department of Soil and Water Use. National Research Centre, Cairo, Egypt \\ *Invited contribution by M. Muñoz-Rojas, recipient of the EGU Outstanding Student Poster (OSP) Award 2012.
}

Correspondence to: M. Muñoz-Rojas (miriammunozrojas@gmail.com)

Received: 18 July 2012 - Published in Solid Earth Discuss.: 21 August 2012

Revised: 30 October 2012 - Accepted: 31 October 2012 - Published: 23 November 2012

\begin{abstract}
Soil C sequestration through changes in land use and management is one of the sustainable and long-term strategies to mitigate climate change. This research explores and quantifies the role of soil and land use as determinants of the ability of soils to store $\mathrm{C}$ along Mediterranean systems. Detailed studies of soil organic C (SOC) dynamics are necessary in order to identify factors determining fluctuations and intensity of changes. In this study, SOC contents from different soil and land use types have been investigated in Andalusia (Southern Spain). We have used soil information from different databases, as well as land use digital maps, climate databases and digital elevation models. The average SOC content for each soil control section (0-25, 25-50 and $50-75 \mathrm{~cm}$ ) was determined and SOC stocks were calculated for each combination of soil and land use type, using soil and land cover maps. The total organic $\mathrm{C}$ stocks in soils of Andalusia is $415 \mathrm{Tg}$ for the upper $75 \mathrm{~cm}$, with average values ranging from $15.9 \mathrm{MgC} \mathrm{ha}^{-1}$ (Solonchaks under "arable land") to $107.6 \mathrm{Mg} \mathrm{Cha}^{-1}$ (Fluvisols from "wetlands"). Up to $55 \%$ of SOC accumulates in the top $25 \mathrm{~cm}$ of soil $(229.7 \mathrm{Tg})$. This research constitutes a preliminary assessment for modelling SOC stock under scenarios of land use and climate change.
\end{abstract}

\section{Introduction}

Soil organic C (SOC) plays an important role in the global C cycle. It is generally assumed that soils are the largest $\mathrm{C}$ sinks in terrestrial ecosystems. Soils act as a source or a sink of atmospheric $\mathrm{CO}_{2}$ and contain approximately twice the amount of $\mathrm{C}$ in the atmosphere, and about three times the amount in vegetation (IPCC, 2000, 2007; Lal, 2004). Soils have the ability to store $\mathrm{C}$ for long periods of time; thus, changes in the size of the soil $\mathrm{C}$ pool could significantly modify the atmospheric $\mathrm{CO}_{2}$ concentration. Additionally, an adequate level of SOC stock is essential to decrease erosion and degradation risks, hold water and nutrients and improve soil structure (Lal, 2004).

Carbon sequestration is a crucial strategy for reducing atmospheric $\mathrm{CO}_{2}$ concentration, contributing to climate change mitigation (Lal, 2003). Globally, soil C pools contain approximately $1550 \mathrm{Gt}$ of organic $\mathrm{C}$ in the top $1 \mathrm{~m}$ (from a total of approximately $2500 \mathrm{GtC}$ ), and SOC sequestration is estimated at 0.4 to $1.2 \mathrm{Pg} \mathrm{Cyr}^{-1}$, equivalent to $6-20 \%$ of the annual release from fossil fuel combustion (Lal, 2004; Houghton, 2005).

On the other hand, the soil C pool is particularly difficult to quantify and in some cases it is assumed to be a fixed fraction or ignored due to lack of data or precise methodologies. During the last years, the need for accurate information on SOC content at the European, national or regional level has 
increased due to the importance of SOC stocks for sustainable use of natural resources.

In addition to the present concern about environmental problems, such as soil degradation and soil contamination, information on SOC stocks is necessary to assess the potential role of soils as $\mathrm{CO}_{2}$ sinks. Reports of national inventories of $\mathrm{C}$ stocks are required under the Kyoto Protocol by the United Nations Framework Convention on Climate Change (e.g. MARM, 2011), to estimate $\mathrm{C}$ emissions to the atmosphere, which requires accurate and reliable estimates of current $\mathrm{C}$ stocks. Carbon inventories and analysis of SOC distribution constitute an essential tool for modelling the effects of different factors involved in SOC sequestration potential.

SOC pools at global scales are difficult to assess due to high spatial variability and different factors affecting soil C dynamics. Among these factors, land use has a strong influence on SOC stocks (Liebens and VanMolle, 2003; Meersmans et al., 2008; Smith, 2008), altering the balance between C losses and sequestration (Ostle et al., 2009). Nevertheless, there are further determinants influencing SOC variability, such as climate and topography (Schulp et al., 2008; Phachomphon et al., 2010). Consequently, SOC estimates are commonly uncertain in areas with heterogeneous land uses and a high variety of climate and site patterns (Leifield et al., 2005) such as the Mediterranean environments. At the same time, soil depth has an important influence on SOC stocks (Grüneberg et al., 2010). Most studies on SOC are restricted to the topsoil, although vertical processes have a considerable effect on SOC variability (VandenBygaart, 2006). The few existing studies that compare the dynamics of SOC in the upper horizons and the subsurface, suggest a variation in depth of factors controlling SOC dynamics, a hypothesis that has not yet been thoroughly investigated (Salome et al., 2010; Albadalejo et al., 2011). Vertical distribution is one of the features of the organic C pool that is not clearly understood together with the relationships with climate and vegetation (Jobbágy and Jackson, 2000).

Several studies have estimated SOC stocks on a large scale by using national and global soil maps and a certain amount of representative soil profiles, or by combining soil and land cover spatial data sets (Batjes, 1996, 2005; Batjes and Dijkshoorn, 1999; Arrouays et al., 2001; Morisada et al., 2004; Bradley et al., 2005; Leifeld et al., 2005). Commonly, inventories are based on a combination of soil land use mapping units and assignment of mean SOC values from soil profiles, which makes it possible to determine patterns in SOC variability related to soil and land use features. However, the reliability of these estimates depends upon the quality and resolution of the land use and soil spatial databases. Moreover, due to the large spatial variability of SOC within the map units, an elevated density of soil sampling points is required to achieve accurate estimates (Liebens and VanMolle, 2003; Martin et al., 2011).

According to Bahn et al. (2009), a key item in future research in the terrestrial $\mathrm{C}$ cycle is an accurate assessment of
SOC pool in ecosystems and regions that have so far been heavily under-represented. Whereas the SOC pool has been studied at global, continental (Eswaran et al., 1993; Liski et al., 2002; Smith, 2004) or regional scales in humid forest systems (Batjes and Dijkshoorn, 1999; Schwartz and Namri, 2002), there is a lack of information on Mediterranean systems. In addition, estimates of SOC stocks may be particularly inaccurate in areas with diverse land use patterns, such as Mediterranean landscapes. In Spain, for example, Rodríguez-Murillo (2001) assessed organic C contents under different types of land use and soil. Nevertheless, there are few studies providing accurate regional SOC estimates based on combined studies of soil land cover data. In general, there is a lack of national-scale studies on soil spatial variability in Spain (Ibáñez et al., 2005) and therefore detailed studies on SOC distribution in soils are necessary (Flores et al., 2007). Future studies on SOC pools need to be carried out in a comparable way, and the access to data sets needs to be facilitated (Bahn et al., 2009). This study comes to fill a gap in SOC assessment in Mediterranean soils.

The objectives of this study are (1) to quantify current SOC contents and SOC stocks in Andalusia (Southern Spain) for each land use and soil type at different soil depths, (2) to assess possible relationships between SOC stocks and environmental variables, and (3) to elaborate a SOC map of the studied area.

This research is part of a global project for developing a land evaluation tool for predicting SOC pool under scenarios of land use and climate change, as a new component of the MicroLEIS Decision Support System (Anaya-Romero et al., 2011; De la Rosa et al., 2004).

The Mediterranean area represents an important challenge to scientists and land managers because of its size, physical complexity, geological and anthropological history (Blondel and Aronson, 1995). The information generated in this study will be a useful basis for modelling SOC processes and designing of management strategies for stabilizing the increasing atmospheric $\mathrm{CO}_{2}$ concentrations by preservation of $\mathrm{C}$ stocks and sequestration in other Mediterranean regions.

\section{Materials and methods}

\subsection{Study area}

Andalusia (Southern Spain) covers an area of approximately $87000 \mathrm{~km}^{2}$ (Fig. 1). The climate is Mediterranean, with dry, hot summers and mild, moderately rainy winters, showing local variations at a detailed scale. Western Atlantic areas are more rainy and humid, whereas the eastern portion has a dry to extremely dry Mediterranean climate. Average annual precipitation ranges between 500 and $700 \mathrm{~mm}$. Average annual temperatures vary between $<10$ and $18^{\circ} \mathrm{C}$, although milder temperatures are observed at the coast border. Elevation varies between 0 and 3479 m a.s.l. (Mulhacén 


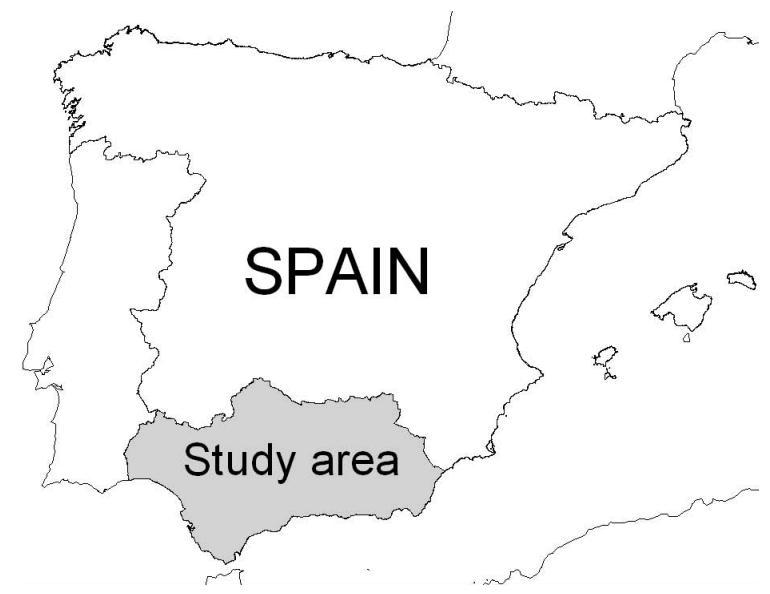

Fig. 1. Study area.

Peak). According to CSIC-IARA (1989), the main soil reference groups are Cambisols, Leptosols, Luvisols, Regosols, and Vertisols.

Most of the natural vegetation is Mediterranean forest, predominantly evergreen trees such as oaks, pines and firs, with dense riparian forests and Mediterranean shrubland. Currently, $45.7 \%$ and $9.6 \%$ of soil is dedicated to farm uses and grasslands, respectively. Agriculture in Andalusia has traditionally been based on wheat crops, olive trees and vineyards. In recent decades, traditional crops have been substituted with intensive and extensive crops (e.g. rice, sugar beet, cotton and sunflower). Likewise, intensive greenhouse crops under plastic have spread through some areas. In the coastal area the decline of traditional crops has been imposed mainly by massive urbanisation and tourist infrastructures.

\subsection{Origin of data and treatment}

\subsubsection{Soil data}

Data from 1479 geo-referenced selected soil profiles reported and described by Jordán and Zavala (2009) and the SEISnet soil database (http://www.evenor-tech.com/banco/ seisnet/seisnet.htm) distributed through the study area have been used to estimate SOC content. These databases contain descriptive and analytical data, including site characteristics, horizon description, chemical and physical analysis. Selection of soil profiles was carried out considering homogeneous sampling and analysis methods.

Variables used in this study were soil depth $(\mathrm{cm})$, organic

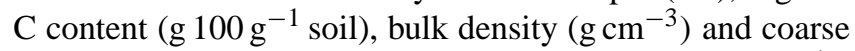

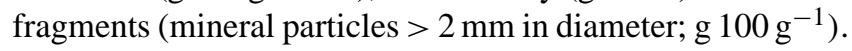
Soil types were described and classified according to FAO (2006). Organic C was determined by dichromate oxidation using the Walkley-Black method (Walkley and Black, 1934). Bulk density was measured by the core method (Blake and Hartge, 1986).
In order to normalise information from soil profiles, data were re-coded and imported to the SDBm Plus Multilingual Soil Profile Database, a geo-referenced soil attribute database that contains a large number of descriptive and analytical data fields (De la Rosa et al., 2002). As soil profiles showed a range of depths, data were homogenised and re-sampled for $0-25,25-50$ and $50-75 \mathrm{~cm}$. The SDBM Plus database incorporates a "control section" function, which allows determining the thickness of the layer to be analysed within the soil profile. This function allows calculating the weighted average value for each variable in standard control sections.

The spatialisation of soil data was carried out following the spatial distribution of soil classes from the Soil Map of Andalusia (CSIC-IARA, 1989) at scale 1:400 000, which contains 2707 polygons classified in 64 soil map units, according to the legend of the soil map of the world (IUSS Working Group WRB, 2006).

\subsubsection{Climate data}

Climate data were obtained from the time series of the CLIMA subsystem of the Environmental Information Network of Andalusia (REDIAM, Andalusian Regional Government) which integrates several databases from a set of over 2200 observatories since 1971 . Selected variables were mean monthly temperature and mean annual precipitation.

\subsubsection{Elevation and slope}

Elevation and slope data were extracted from the $100 \mathrm{~m}$ resolution digital elevation model (DEM) of Andalusia (ICA, 1999) derived from the topographic map of Andalusia (S $1: 10000)$.

\subsubsection{Land use and land cover data}

Land use classification and land cover data for this study were taken from the Land Use and Land Cover Map of Andalusia (LULCMA) for 2007 at scale 1:25000 and minimum map unit 0.5 ha (Moreira, 2007). This digital spatial data set, obtained after the analysis of satellite images (Landsat TM, IRS/PAN and SPOT-5) and digital aerial photographs, is a result of the Coordination of Information on the Environment (CORINE) programme, promoted by the European Commission in 1985 for the assessment of environmental quality in Europe.

Within the CORINE programme, the CORINE Land Cover project (CLC) provides consistent information on land cover and land cover changes across Europe (Anaya-Romero et al., 2011). The LULCMA provides an updated version of the original maps at scale 1:100000 and constitutes more detailed and accurate databases, both thematically and geometrically. Land use and land cover changes (LULCC) were assessed visually and gaps/errors were substituted with revised data from different origins or direct observations. Land cover classes of LULCMA were reclassified into CLC 
standard nomenclatures, in order to make the methodology available for other CORINE programme member countries and obtain easily comparable results (Muñoz-Rojas et al., 2011).

The standard CLC nomenclature includes 44 land cover classes, grouped in a three-level hierarchy. The 5 main classes (level 1) describe land patterns for use on a planet scale, comprising the following categories: (1) "Artificial surfaces", (2) "Agricultural areas", (3) "forests" and seminatural areas", (4) "Wetlands", and (5) "Water bodies" (Heymann et al., 1994). Level 2 (15 classes) corresponds to physical and physiognomic entities at scales $1: 500000$ and $1: 1000000$ ("Urban zones", "forests", "Lakes", etc.). Finally, level 3 is composed of acutely defined 44 classes for use on scale 1:100000 and higher ("Residential areas", "Airport", "Commercial areas", etc.). All national working groups adopted this standard nomenclature, although it has been improved over the years by introducing local subclasses.

\subsection{Soil organic C stock calculation}

For each soil layer $(0-25,25-50$ and $50-75 \mathrm{~cm})$ of the 1479 soil profiles, soil organic C content (SOCC) was estimated as follows:

$\mathrm{SOCC}=\mathrm{SOC} \times \mathrm{BD} \times D \times(1-G)$

where SOCC is soil organic $\mathrm{C}$ content $\left(\mathrm{Mgha}^{-1}\right)$, SOC is soil organic C percentage $\left(\mathrm{g} 100^{-1} \mathrm{~g}^{-1}\right)$, BD is bulk density $\left(\mathrm{g} \mathrm{cm}^{-3}\right), D$ is the thickness of the studied layer $(\mathrm{cm})$ and $G$ is the proportion in volume of coarse fragments

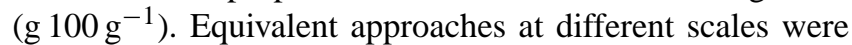
used by Rodríguez-Murillo (2001) in peninsular Spain and by Boix-Fayos et al. (2009) in Murcia (SE Spain). Soil profiles were classified according to original soil profile descriptions, into 10 soil reference groups (IUSS Working Group WRB, 2006): Arenosols, Calcisols, Cambisols, Fluvisols, Leptosols, Luvisols, Planosols, Regosols, Solonchaks and Vertisols, and 7 land use types (following CLC nomenclature at level 2: "arable land", "permanent crops", "heterogeneous agricultural areas", "forest", "scrub and/or vegetation associations", "open spaces with little or no vegetation", and "maritime wetlands").

Data analysis was performed using SPSS (SPSS, 2009) and ArcGIS (ESRI, 2006) software packs. To determine SOC for each soil class within every land cover type, the study area was divided into "land use soil association units" (landscape units) using a topological intersection of the LULCMA for 2007 and the Soil Map of Andalusia. The overlay of both maps resulted in 85492 new polygons, defined by 1 soil class (dominant unit) and one aggregated land cover type.

Mean values of SOCC of each land use soil class was assigned to all the new polygons. Soil organic $\mathrm{C}$ stocks for each soil class were determined by multiplying SOCC mean val- ues by the area occupied by the land use soil unit in the overlay map.

\subsection{Relationships between soil organic $\mathrm{C}$ content and environmental variables}

In order to identify the influence of environmental factors (climate and site factors) on SOC, correlation analyses were performed using Statistica (StatSoft, 2001). The following variables were considered: mean annual precipitation ( $\mathrm{mm}$ ), mean winter (December-February) and summer (June-August), temperature, elevation and slope. Analyses were carried out for the total set of soil profiles, and for different soil types and land use classes. A number of soil profiles, classified as Planosols, Solonchaks and soils from "maritime wetlands" were not considered in the analysis because of the absence of SOC variation with environmental variables.

Elevation and slope data for each profile were extracted from the DEM, and climate variables (mean annual rainfall and mean summer and winter temperature), were obtained from the climate spatial data sets in raster format. Data analysis was performed using ArcGIS spatial analyst extension tool (ESRI, 2006).

\section{Results}

\subsection{Soil organic $\mathrm{C}$ contents from main land use and soil types}

The total area of soils under "arable land", "permanent crops", "heterogeneous agricultural area", "forest", "scrub and/or vegetation associations", "open spaces with little or no vegetation", and "maritime wetlands", identified using the Soil Map of Andalusia and LULCMA, was $83686.74 \mathrm{~km}^{2}$ (Table 1). Ten major soil groups occur in the study area. Cambisols (42.7\% of the studied area) and Regosols $(19.7 \%)$ are most common, followed by Vertisols $(8.8 \%)$, Leptosols (8.6\%), and Luvisols (8.3\%). These five major groups account for about $73744.74 \mathrm{~km}^{2}(88.1 \%$ of the studied area).

Soil organic C content (SOCC) and coefficient of variation (CV) were calculated for each land use and soil type combination/association in the study area (Table 2). Values are shown for $0-25,25-50,50-75$ and $0-75 \mathrm{~cm}$ depths.

On average, Calcisols, Regosols and Solonchaks have the highest SOCC values, above $55 \mathrm{Mg} \mathrm{Cha}^{-1}$ while Arenosols and Leptosols show the lowest amounts, below $40 \mathrm{Mg} \mathrm{Cha}^{-1}$ (Table 2, Fig. 2). Likewise, SOCC is considerably lower in "open spaces with little or no vegetation" compared to the other land use types, and "maritime wetlands" have the highest SOCC of all land use classes (Table 2, Fig. 3).

The highest SOCC values in the first $25 \mathrm{~cm}$ of soil were observed in Fluvisols and Solonchaks under "maritime wetlands", which store more than $50 \mathrm{MgCha}^{-1}$ (Table 2). 
Table 1. Area $\left(\mathrm{km}^{2}\right)$ and SOC stocks (SOC stock, Tg) under main land uses types and soil groups.

\begin{tabular}{|c|c|c|c|c|c|c|c|c|c|c|c|c|c|c|c|c|}
\hline \multirow[b]{2}{*}{ Soil group } & \multicolumn{2}{|c|}{ "Arable land" } & \multicolumn{2}{|c|}{ "Permanent crops" } & \multicolumn{2}{|c|}{$\begin{array}{c}\text { "Heterogeneous, } \\
\text { agricultural areas" }\end{array}$} & \multicolumn{2}{|c|}{ "Forest" } & \multicolumn{2}{|c|}{$\begin{array}{l}\text { Scrub and/or } \\
\text { herbaceous } \\
\text { vegetation } \\
\text { associations }\end{array}$} & \multicolumn{2}{|c|}{$\begin{array}{c}\text { "Open spaces with } \\
\text { little or no } \\
\text { vegetation" }\end{array}$} & \multicolumn{2}{|c|}{$\begin{array}{l}\text { "Maritime } \\
\text { wetlands" }\end{array}$} & \multicolumn{2}{|c|}{ Total } \\
\hline & Area & SOCS & Area & SOCS & Area & SOCS & Area & SOCS & Area & SOCS & Area & SOCS & Area & SOCS & Area & SOCS \\
\hline Arenosol & 75.00 & 0.22 & 19.23 & 0.06 & 17.66 & 0.09 & 158.95 & 0.53 & 150.77 & 0.66 & 12.40 & 0.02 & 43.10 & 0.00 & 477.12 & 1.57 \\
\hline Calcisol & 418.44 & 2.75 & 118.92 & 0.66 & 323.62 & 2.66 & 35.34 & 0.34 & 823.90 & 5.46 & 15.52 & 0.00 & 1.66 & 0.00 & 1737.40 & 11.88 \\
\hline Cambisol & 4513.96 & 21.33 & 7296.52 & 43.69 & 6351.18 & 21.93 & 7990.29 & 26.41 & 9352.92 & 49.30 & 205.01 & 0.00 & 16.21 & 0.00 & 35726.09 & 162.66 \\
\hline Fluvisol & 1454.13 & 7.97 & 961.37 & 5.91 & 613.15 & 3.77 & 435.89 & 2.05 & 775.91 & 2.97 & 23.49 & 0.00 & 65.62 & 0.71 & 4329.57 & 23.39 \\
\hline Leptosol & 255.75 & 0.99 & 542.77 & 1.50 & 352.12 & 1.32 & 1755.01 & 7.19 & 4175.28 & 16.87 & 91.67 & 0.41 & 0.00 & 0.00 & 7172.58 & 28.29 \\
\hline Luvisol & 1522.38 & 8.09 & 2389.15 & 13.69 & 866.75 & 4.42 & 982.42 & 5.84 & 1193.73 & 6.09 & 20.50 & 0.00 & 8.81 & 0.00 & 6983.74 & 38.13 \\
\hline Planosol & 722.15 & 4.22 & 416.67 & 0.00 & 171.06 & 0.00 & 374.67 & 0.00 & 206.29 & 0.52 & 9.20 & 0.00 & 16.15 & 0.00 & 1916.20 & 4.74 \\
\hline Regosol & 2040.71 & 12.99 & 3888.70 & 19.58 & 1637.16 & 6.81 & 3616.00 & 20.09 & 5150.77 & 31.85 & 152.03 & 0.57 & 32.81 & 0.06 & 16518.18 & 91.95 \\
\hline Solonchak & 923.80 & 1.46 & 11.89 & 0.00 & 80.23 & 0.00 & 42.91 & 0.00 & 64.12 & 0.34 & 17.39 & 0.00 & 341.36 & 2.42 & 1481.70 & 4.22 \\
\hline Vertisol & 3542.16 & 24.57 & 1630.43 & 9.55 & 973.77 & 7.26 & 519.88 & 5.13 & 668.29 & 1.85 & 8.23 & 0.00 & 1.39 & 0.00 & 7344.15 & 48.37 \\
\hline Total & 15468.49 & 84.59 & 17275.66 & 94.65 & 11386.70 & 48.27 & 15911.37 & 67.60 & 22561.98 & 115.92 & 555.43 & 1.00 & 527.12 & 3.19 & 83686.74 & 415.21 \\
\hline
\end{tabular}

Table 2. Carbon stocks for land use soil combinations at different soil depths $(0-25,25-50$ and $0-75 \mathrm{~m})\left(\mathrm{Mg} \mathrm{ha}^{-1}\right) . N$ : number of values, SOCC: Soil organic C content, CV: coefficient of variation, na: insufficient number of samples to provide statistics (not available).

\begin{tabular}{|c|c|c|c|c|c|c|c|c|c|c|c|c|c|c|c|c|c|c|c|c|c|c|c|c|c|}
\hline \multirow[b]{2}{*}{ Soil group } & \multirow{2}{*}{$\begin{array}{r}\text { Soil } \\
\text { depth } \\
(\mathrm{cm})\end{array}$} & \multicolumn{3}{|c|}{ "Arable land" } & \multicolumn{3}{|c|}{ "Permanent crops" } & \multicolumn{3}{|c|}{$\begin{array}{c}\text { "Heterogeneous } \\
\text { agricultural areas" }\end{array}$} & \multicolumn{3}{|c|}{ "Forest" } & \multicolumn{3}{|c|}{$\begin{array}{c}\text { Scrub and/or } \\
\text { herbaceous } \\
\text { vegetation } \\
\text { associations }\end{array}$} & \multicolumn{3}{|c|}{$\begin{array}{l}\text { "Open spaces with } \\
\text { little or no } \\
\text { vegetation" }\end{array}$} & \multicolumn{3}{|c|}{$\begin{array}{l}\text { "Maritime } \\
\text { wetlands" }\end{array}$} & \multicolumn{3}{|c|}{ Total } \\
\hline & & $N$ & SOCC & $\mathrm{CV}$ & $N$ & SOCC & $\mathrm{CV}$ & $N$ & SOCC & $\mathrm{CV}$ & $N$ & SOCC & $\mathrm{CV}$ & $N$ & SOCC & $\mathrm{CV}$ & $N$ & SOCC & $\mathrm{CV}$ & $N$ & SOCC & $\mathrm{CV}$ & $N$ & SOCC & $\mathrm{CV}$ \\
\hline \multirow[t]{4}{*}{ Arenosol } & $0-25$ & 5 & 18.6 & 94.5 & 6 & 16.4 & 84.8 & 10 & 34.1 & 33.9 & 28 & 25.8 & 58.2 & 20 & 29.9 & 78.1 & 2 & 16.2 & 126.7 & 0 & na & na & 71 & 26.5 & 67.1 \\
\hline & $25-50$ & & 3.5 & 101.3 & & 15.2 & 107.7 & & 10.3 & 75.5 & & 5.2 & 151.3 & & 8.3 & 173.6 & & 0.8 & 141.4 & & na & na & & 7.3 & 150.1 \\
\hline & $50-75$ & & 0.1 & 175.2 & & 0.95 & 189.1 & & 5.9 & 135.6 & & 2.2 & 224.8 & & 5.3 & 181.2 & & 0.0 & & & na & na & & 3.8 & 199.9 \\
\hline & Total & & 22.1 & 70.2 & & 32.5 & 91.6 & & 50.2 & 33.9 & & 33.2 & 57.3 & & 43.5 & 95.8 & & 17.0 & 127.4 & & na & na & & 37.7 & 74.6 \\
\hline \multirow[t]{4}{*}{ Calcisol } & $0-25$ & 80 & 35.5 & 53.8 & 59 & 29.2 & 62.8 & 7 & 50.1 & 65.5 & 26 & 50.7 & 57.7 & 14 & 45.9 & 56.6 & 0 & na & na & 0 & na & na & 186 & 36.9 & 61.7 \\
\hline & $25-50$ & & 23.3 & 84.4 & & 18.7 & 89.6 & & 25.5 & 62.6 & & 27.5 & 58.8 & & 19.2 & 113.6 & & na & na & & na & na & & 22.2 & 83 \\
\hline & $50-75$ & & 7.0 & 179.3 & & 7.9 & 183.9 & & 6.6 & 175.5 & & 15.7 & 101.7 & & 1.2 & 374.2 & & na & na & & na & na & & 8.0 & 169.4 \\
\hline & Total & & 65.8 & 56.8 & & 55.6 & 65.1 & & 82.2 & 42.3 & & 96.9 & 46.0 & & 66.3 & 62.4 & & na & na & & na & na & & 67.6 & 59.4 \\
\hline \multirow[t]{4}{*}{ Cambisol } & $0-25$ & 54 & 19.6 & 94.7 & 15 & 30.2 & 39.1 & 35 & 22.6 & 86.8 & 99 & 19.3 & 137.1 & 35 & 30.7 & 104.9 & 0 & na & na & 0 & na & na & 238 & 22.2 & 110.1 \\
\hline & $25-50$ & & 16.3 & 98.3 & & 18.3 & 63.9 & & 8.3 & 113.1 & & 8.9 & 151.9 & & 15.5 & 136.5 & & na & na & & na & na & & 12.0 & 126.5 \\
\hline & $50-75$ & & 11.4 & 121.2 & & 11.4 & 78.7 & & 3.7 & 187.8 & & 4.9 & 210.8 & & 6.6 & 160.6 & & na & na & & na & na & & 6.8 & 162.2 \\
\hline & Total & & 47.3 & 91.7 & & 59.9 & 46.4 & & 34.5 & 89.4 & & 33.1 & 143.6 & & 52.7 & 97.9 & & na & na & & na & na & & 41.1 & 108.9 \\
\hline Fluvisol & $0-25$ & 28 & 26.7 & 68.5 & 1 & 29.5 & na & 13 & 29.9 & 66.8 & 17 & 19.3 & 120.3 & 13 & 26.9 & 103.5 & 0 & na & na & 1 & 73.6 & na & 73 & 26.3 & 84 \\
\hline & $25-50$ & & 20.8 & 71.8 & & 32.0 & na & & 21.7 & 65.3 & & 18.3 & 117.8 & & 5.8 & 118.7 & & na & na & & 20.3 & na & & 17.9 & 90.9 \\
\hline & $50-75$ & & 7.3 & 167.4 & & 0.0 & na & & 9.9 & 135.9 & & 9.6 & 153.8 & & 5.6 & 221.3 & & na & na & & 13.7 & na & & 8.0 & 160.4 \\
\hline & Total & & 54.8 & 53.0 & & 61.5 & na & & 61.5 & 61.3 & & 47.1 & 118.1 & & 38.3 & 92.0 & & na & na & & 107.6 & na & & 52.1 & 75.6 \\
\hline Leptosol & $0-25$ & 19 & 27.7 & 98.9 & 14 & 20.2 & 82.5 & 54 & 33.6 & 97.6 & 143 & 33.6 & 111.0 & 105 & 34.5 & 100.3 & 2 & 44.6 & 122.0 & 0 & na & na & 337 & 33.1 & 104.7 \\
\hline & $25-50$ & & 9.1 & 158.4 & & 5.5 & 144.7 & & 3.9 & 269.4 & & 6.3 & 350.6 & & 4.9 & 257.8 & & 0.0 & & & na & na & & 5.6 & 304.5 \\
\hline & $50-75$ & & 1.8 & 435.9 & & 2.1 & 195.3 & & 0.0 & 734.9 & & 1.1 & 512.7 & & 0.9 & 471.8 & & 0.0 & & & na & na & & 0.9 & 512.8 \\
\hline & Total & & 38.6 & 94.3 & & 27.7 & 67.0 & & 37.6 & 94.3 & & 41.0 & 126.3 & & 40.4 & 100.2 & & 44.6 & 122.0 & & na & na & & 39.6 & 111.2 \\
\hline Luvisol & $0-25$ & 34 & 25.1 & 82.6 & 30 & 25.6 & 70.7 & 15 & 24.8 & 143.3 & 41 & 33.9 & 103.1 & 24 & 28.7 & 132.1 & 0 & na & na & 0 & na & na & 144 & 28.2 & 104.7 \\
\hline & $25-50$ & & 17.8 & 93.4 & & 18.5 & 80.3 & & 15.3 & 174.7 & & 15.2 & 107.8 & & 15.1 & 128.8 & & na & na & & na & na & & 16.5 & 107.9 \\
\hline & $50-75$ & & 10.2 & 124.5 & & 13.3 & 99.8 & & 11.0 & 227.6 & & 10.4 & 115.1 & & 7.3 & 191.9 & & na & na & & na & na & & 10.5 & 137.7 \\
\hline & Total & & 53.2 & 78.45 & & 57.3 & 73.8 & & 51.0 & 152.7 & & 59.5 & 100.5 & & 51.0 & 127.7 & & na & na & & na & na & & 55.2 & 100 \\
\hline Planosol & $0-25$ & 2 & 28.8 & 22.9 & 0 & na & na & 0 & na & na & 0 & na & na & 1 & 17.6 & na & 0 & na & na & 0 & na & na & 3 & 25.1 & 31.8 \\
\hline & $25-50$ & & 16.5 & 13.0 & & na & na & & na & na & & na & na & & 7.7 & na & & na & na & & na & na & & 13.5 & 39 \\
\hline & 50-75 & & 13.2 & 7.3 & & na & na & & na & na & & na & na & & 0.0 & na & & na & na & & na & na & & 8.8 & 86.9 \\
\hline & Total & & 58.5 & 16.6 & & na & na & & na & na & & na & na & & 25.3 & na & & na & na & & na & na & & 47.4 & 42.9 \\
\hline Regosol & $0-25$ & 56 & 31.9 & 66.4 & 53 & 24.8 & 73.2 & 33 & 21.5 & 112.7 & 111 & 34.6 & 87.7 & 71 & 35.5 & 80.9 & 4 & 29.9 & 32.5 & 1 & 19.0 & na & 329 & 31.3 & 84.1 \\
\hline & $25-50$ & & 22.1 & 70.5 & & 17.8 & 79.1 & & 12.5 & 196.5 & & 16.5 & 131.6 & & 16.9 & 147.1 & & 7.4 & 165.9 & & 0.0 & na & & 17.2 & 120.8 \\
\hline & $50-75$ & & 9.7 & 150.6 & & 7.7 & 162.2 & & 7.7 & 286.3 & & 4.5 & 198.1 & & 9.4 & 222.2 & & 0.0 & & & 0.0 & na & & 7.2 & 211.5 \\
\hline & Total & & 63.7 & 60.2 & & 50.4 & 62.6 & & 41.6 & 153.4 & & 55.6 & 92.0 & & 61.8 & 104.7 & & 37.3 & 46.3 & & 19.0 & na & & 55.7 & 92 \\
\hline Solonchak & $0-25$ & 2 & 11.1 & 65.8 & 0 & na & na & 0 & na & na & 0 & na & na & 8 & 30.1 & 44.8 & 0 & na & na & 10 & 50.4 & 50.5 & 20 & 38.4 & 61.7 \\
\hline & $25-50$ & & 2.1 & 141.4 & & na & na & & na & na & & na & na & & 17.0 & 79.1 & & na & na & & 17.4 & 121.1 & & 15.7 & 110.1 \\
\hline & $50-75$ & & 2.6 & 141.4 & & na & na & & na & na & & na & na & & 6.5 & 163.7 & & na & na & & 3.0 & 290.8 & & 4.3 & 207.2 \\
\hline & Total & & 15.9 & 3.8 & & na & na & & na & na & & na & na & & 53.6 & 60.0 & & na & na & & 70.8 & 49.8 & & 58.4 & 60.5 \\
\hline Vertisol & $0-25$ & 51 & 28.4 & 48.7 & 13 & 25.2 & 54.8 & 2 & 38.5 & 8.5 & 5 & 42.4 & 18.9 & 7 & 13.1 & 127.9 & 0 & na & na & 0 & na & na & 78 & 27.6 & 53.3 \\
\hline & $25-50$ & & 23.0 & 57.1 & & 17.8 & 54.3 & & 31.3 & 24.8 & & 35.9 & 25.7 & & 8.9 & 146.9 & & na & na & & na & na & & 21.9 & 61.1 \\
\hline & $50-75$ & & 18.1 & 81.7 & & 15.7 & 67.4 & & 4.8 & 141.4 & & 20.4 & 64.1 & & 5.7 & 189.6 & & na & na & & na & na & & 16.4 & 85.2 \\
\hline & Total & & 69.4 & 44.8 & & 58.6 & 43.3 & & 74.6 & 3.1 & & 98.7 & 14.9 & & 27.7 & 146.3 & & na & na & & na & na & & 65.8 & 50.1 \\
\hline Total & $0-25$ & 331 & 28.5 & 69.6 & 191 & 26.1 & 66.2 & 169 & 28.7 & 96 & 470 & 39.9 & 103.8 & 298 & 33.1 & 94.5 & 8 & 30.1 & 83.8 & 12 & 49.7 & 52 & 1479 & 30.1 & 91.1 \\
\hline & $25-50$ & & 19.8 & 84.2 & & 17.3 & 84.4 & & 10.5 & 164.4 & & 11.9 & 167 & & 11.2 & 168.7 & & 3.9 & 227 & & 16.2 & 122 & & 0.14 & 130.7 \\
\hline & $50-75$ & & 10.0 & 137.9 & & 8.8 & 144.1 & & 4.7 & 294.7 & & 4.9 & 208 & & 4.9 & 264.8 & & na & na & & 3.6 & 234.5 & & 6.5 & 193.6 \\
\hline & Total & & 58.3 & 65.4 & & 52.2 & 65.3 & & 43.8 & 106.2 & & 47.8 & 51.9 & & 49.1 & 103.6 & & 34.1 & 79.8 & & 69.6 & 53.5 & & 50.6 & 91.2 \\
\hline
\end{tabular}

Calcisols under "heterogeneous agricultural areas" and "forest" stored 50.1 and $50.7 \mathrm{MgC} \mathrm{ha}^{-1}$, respectively. Solonchaks under "arable land" and Vertisols under "Scrub and/or herbaceous vegetation associations", have the lowest SOCC values, storing less than $14 \mathrm{MgCha}^{-1}$. The average SOCC distribution with depth is similar in all land use soil class combinations, decreasing rapidly with increasing soil depth and tending to near-zero values below $50 \mathrm{~cm}$ for soils under "open spaces with little or no vegetation" (Arenosols, Leptosols and Regosols). Calcisols under "forest" store high amounts of SOC at larger depths comparing to other 


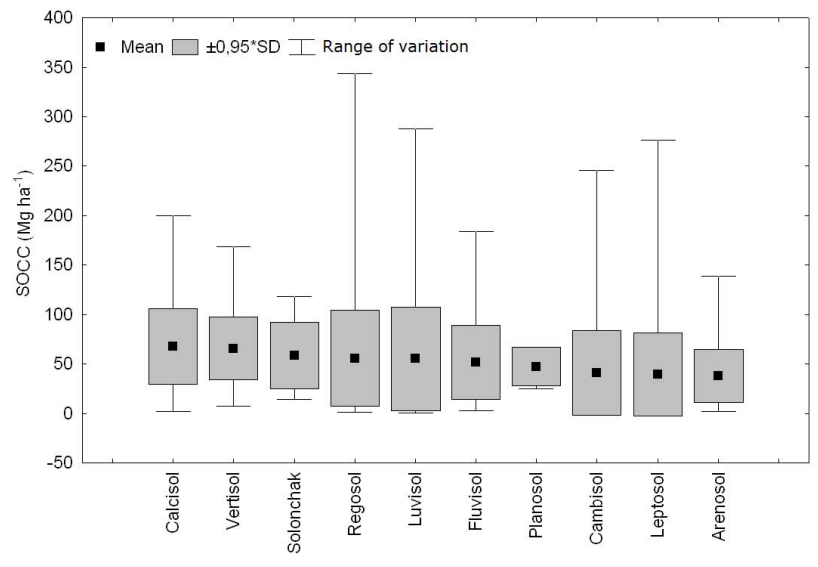

Fig. 2. Soil organic carbon content (SOCC) for the major soil groups in the study area. SD: standard deviation $(0-75 \mathrm{~cm})$.

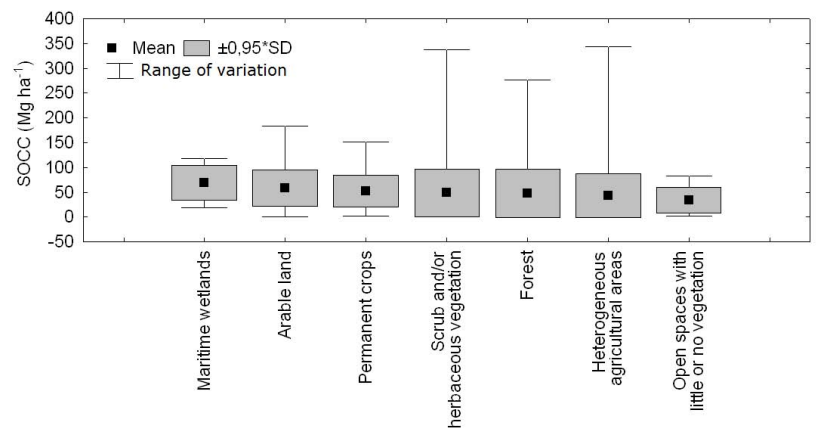

Fig. 3. Soil organic carbon content (SOCC) for each land use type. SD: standard deviation $(0-75 \mathrm{~cm})$.

soil groups with SOCC values above $27 \mathrm{MgCha}^{-1}$ and $15 \mathrm{MgC} \mathrm{ha}^{-1}$ in the layers $25-50 \mathrm{~cm}$ and $50-75 \mathrm{~cm}$.

Values of SOCC in the entire depth down to $75 \mathrm{~cm}$ range between $107.6 \mathrm{MgCha}^{-1}$ for Fluvisols under "maritime wetlands" and $15.9 \mathrm{MgC} \mathrm{ha}^{-1}$ for Solonchaks under "arable land". A large variation in SOC exists within each land use soil class association with $\mathrm{CV}$ ranging between $3.8 \%$ for Solonchaks under "arable land" and $152.7 \%$ for Luvisols under "heterogeneous agricultural areas".

\subsection{SOC stocks from main land use and soil types}

Total stocks per land use class and soil type (in absolute terms) are given in Table 1. "Scrub and /or vegetation associations" contain $115.92 \mathrm{Tg} \mathrm{C}$ in $22561.98 \mathrm{~km}^{2}$, "permanent crops" $94.65 \mathrm{TgC}$ in $17275.66 \mathrm{~km}^{2}$, "arable land" $84.59 \mathrm{Tg} \mathrm{C}$ in $15468.49 \mathrm{~km}^{2}$ and "forest" $67.60 \mathrm{TgC}$ in $15911.37 \mathrm{~km}^{2}$. Soils with the largest SOC stock are Cambisols (162.66 Tg), Regosols (91.95 Tg) and Vertisols (48.37 Tg).

The estimated SOC stock in the upper $75 \mathrm{~cm}$ is $415 \mathrm{Tg}$ (Table 1). Accumulated $C$ stocks for each soil type and land use

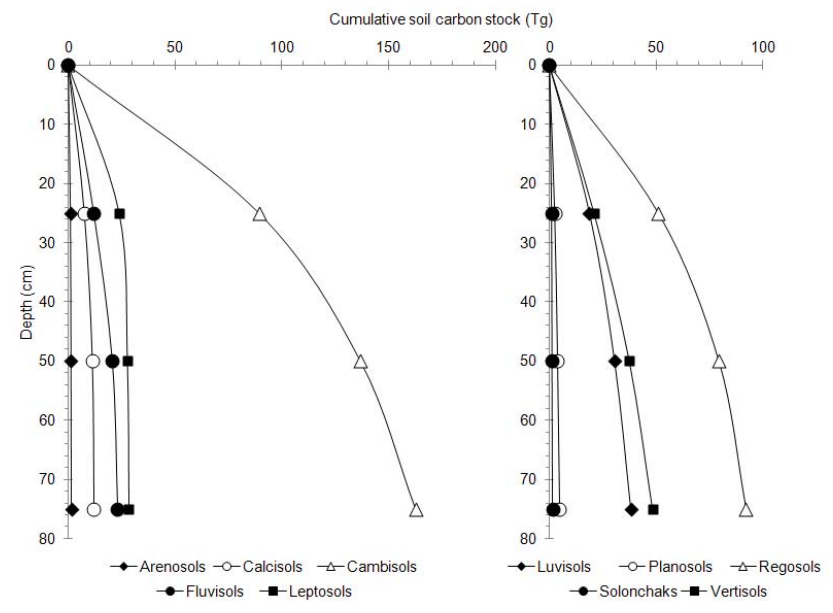

Fig. 4. Cumulative soil organic carbon stock in depth for each soil class.

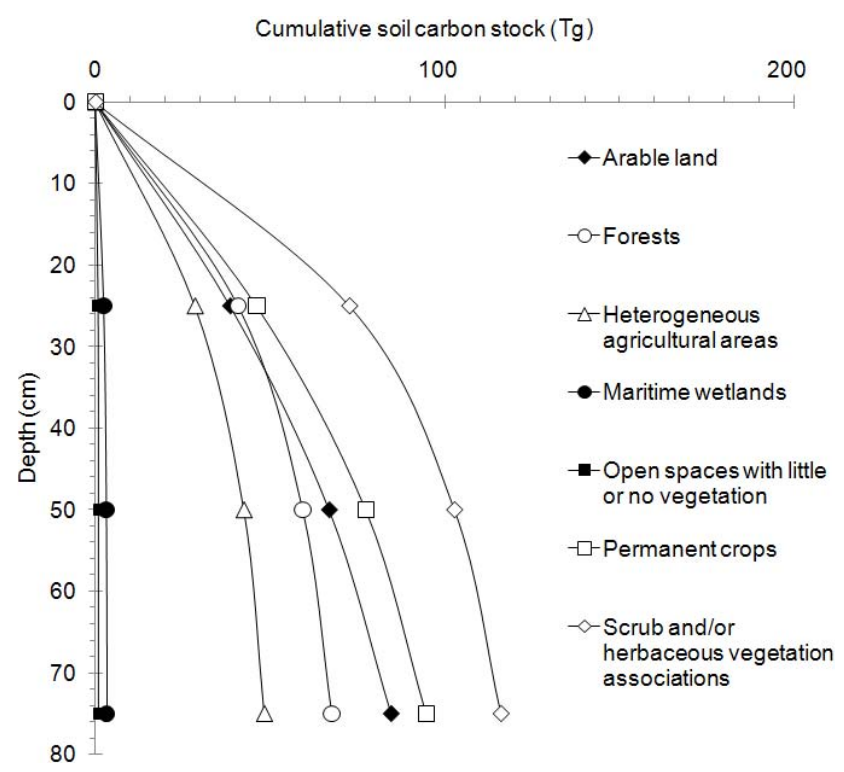

Fig. 5. Cumulative soil organic carbon stock in depth for each land use type.

class are shown in Figs. 4 and 5, respectively. All soil groups store more than $50 \%$ of total $\mathrm{C}$ in the first $25 \mathrm{~cm}$, except Vertisols which accumulates less than $45 \%$. The proportion of SOC stock in the $0-25 \mathrm{~cm}$ layer is on average about $55 \%$ $(229.69 \mathrm{Tg}$ ) of the total SOC stock in the upper $75 \mathrm{~cm}$, around $30 \%(122.89 \mathrm{Tg})$ in the $25-50 \mathrm{~cm}$ layer and $15 \%(62.62 \mathrm{Tg})$ in the deepest layer $(50-75 \mathrm{~cm})$ (Figs. 4 and 5). Among all land use types, agricultural uses such as "arable land" and "permanent crops" show low percentages of SOC stock in the first layer (below $50 \%$ ).

Current spatial distribution of SOCC per land use soil association unit $\left(\mathrm{MgC} \mathrm{ha}^{-1}\right)$ in Andalusia is shown in Fig. 6. 


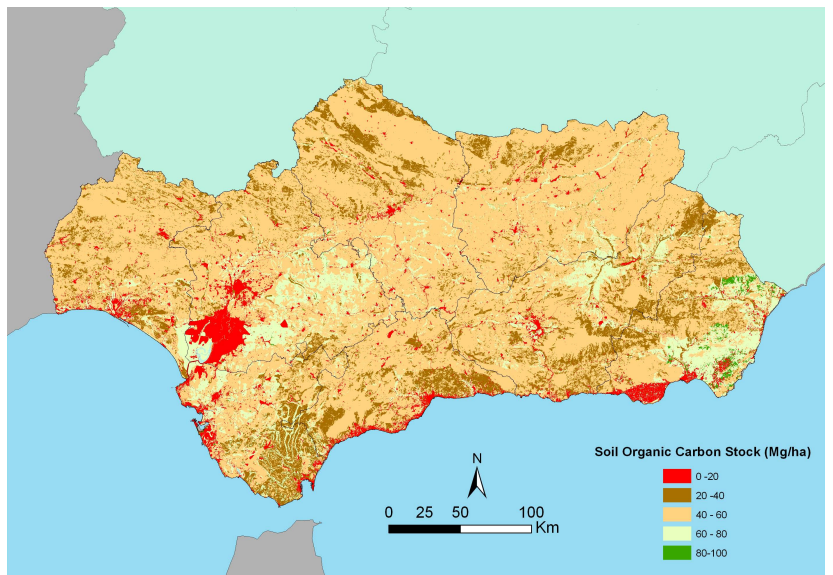

Fig. 6. Map of soil organic carbon content $(0-75 \mathrm{~cm})$ in Andalusia.

\subsection{Relationships between SOC and environmental data}

Statistical analysis of correlations between SOC contents and environmental factors is shown in Table 3. Mean values, standard deviation and correlation coefficients have been obtained for each variable and SOC in the total data set and land use/soil type groups.

Considering all the soil profiles, SOC was negatively correlated with slope $(r=-0.2900)$. The analysis did not show significant correlations with other variables.

SOC was positively correlated with winter temperature in Cambisols and Luvisols $(r=0.9550$ and $r=0.8249)$ and negatively correlated with summer temperature $(r=$ -0.8291 ) in Fluvisols. In Vertisols, a significant negative correlation was found with elevation $(r=-0.9511)$.

Among land uses, SOC showed a positive correlation with winter temperature in "heterogeneous agricultural areas" $(\mathrm{r}=0.9319)$ and a negative correlation with summer temperature in "forest" $(r=-0.8794)$. Elevation is also well correlated with SOC in "heterogeneous agricultural areas" $(r=-0.8818)$

In both natural land use types ("heterogeneous agricultural areas" and "forest"), significant correlations were found with SOC and annual precipitation. However, whereas in "forest" the correlation was positive ( $r=0.7908)$, in "heterogeneous agricultural areas" SOC was negatively correlated with precipitation $(r=-0.7454)$.

\section{Discussion}

\subsection{Soil C stocks}

Studies on the spatial distribution of SOC in relation with soil types have been carried out by many authors. Liebens and VanMolle (2003), for example, evaluated different methodologies for assessing SOC stock in Flanders, Belgium, in which SOC densities were assigned to polygons on the digital soil map of Flanders. For the total area of Belgium, Lettens et al. (2005) used a topological intersection of CLC geo-data sets and a digitized soil association map and soil $\mathrm{C}$ data from different data sets to plot the distribution of soil C stocks in the country. Also, in France, Arraouays et al. (2001) took into account both forest soil types and vegetation cover. Then $\mathrm{C}$ densities were determined by soil land use category using a combination of geo-referenced soil and CORINE land use databases. The same approach was used in Great Britain by Howard et al. (1995), who mapped the geographical distribution of SOC with estimates based on the dominant soil series and land cover class for $1 \mathrm{~km} \times 1 \mathrm{~km}$ blocks.

Nevertheless, studies concerning both soil type and land use combined data are scarce, especially in Mediterranean areas. Different soil types show a range of capacities for C sequestration due to soil inherent potential (based on texture, mineralogy, etc.) to retain organic C (Gibson et al., 2002) and therefore, both soil and land use data should be used in determining soil $\mathrm{C}$ stocks.

A number of studies have been carried out in different regions of Spain concerning SOC stocks under main land uses and/or soil types (Boix-Fayos et al., 2009; Díaz-Hernández et al., 2003; Ganuza and Almendros, 2003; Jordán López et al., 2007). One of the most complete is the work conducted by Rodríguez-Murillo (2001), in which stock and spatial distribution of SOC in peninsular Spain was determined using soil profile descriptions available in literature.

Our estimates are in agreement with the results obtained in Mediterranean areas by other authors. Among the major soil types, the largest average SOCC is found in Calcisols, and Vertisols (Fig. 2). Most of Calcisols occur under "Scrub and/or herbaceous associations" and values of SOC stocks for Calcisols obtained in this research are generally larger than those found by several authors (e.g. Rodríguez-Murillo, 2001). However, determined SOCCs are similar to those estimated by Díaz-Hernández et al. (2003) in southeastern Spain, with $52 \mathrm{MgC} \mathrm{ha}^{-1}$ at $0.5 \mathrm{~m}$ depth and $70 \mathrm{MgCha}^{-1}$ at $1 \mathrm{~m}$ depth.

A high SOC content in Vertisols, which are naturally fertile soils, may be explained by its high clay content and consequently high moisture storage capacity. Similar values of SOCCs for Vertisols were reported in Spain by Rodríguez-Murillo (2001), $68.9 \mathrm{MgC} \mathrm{ha}^{-1}$, and in Jordan by Batjes (2006), $37 \mathrm{MgCha}^{-1}$ at $0.3 \mathrm{~m}$ depth and $75 \mathrm{MgCha}^{-1}$ at $1 \mathrm{~m}$ depth with $59 \mathrm{MgCha}^{-1}$ for "arable land" and $68{\mathrm{Mg} \mathrm{C}, \mathrm{ha}^{-1}}^{-}$for "forest" at $1 \mathrm{~m}$ depth. Moreover, in Tunisia, Brahim et al. (2010) estimated $45.6 \mathrm{Mg} \mathrm{Cha}^{-1}$ at $30 \mathrm{~cm}$ depth and $109.7 \mathrm{MgCha}^{-1}$ at $1 \mathrm{~m}$ depth. Higher values were found in Central and Eastern Europe by Batjes (2002), with $82 \mathrm{MgC} \mathrm{ha}^{-1}$ at $0.3 \mathrm{~m}$ and $236 \mathrm{MgCha}^{-1}$ at $1 \mathrm{~m}$ depth.

A low SOC content is observed for coarse textured Arenosols. However, values encountered in this soil class 
Table 3. Mean soil organic carbon content $\left(\mathrm{Mgha}^{-1}\right)$ and standard deviation for each soil and land use type and correlation coefficients between soil organic carbon content and environmental variables. $(*) p \leq 0.05 ;(* *) p \leq 0.01 ;(* *) p \leq 0.001$. Non-significant correlation coefficients are not marked.

\begin{tabular}{|c|c|c|c|c|c|c|c|c|c|}
\hline Type & Group & $N$ & Mean & Std. Dev. & $\begin{array}{r}\text { Winter } \\
\text { temperature }\end{array}$ & $\begin{array}{r}\text { Summer } \\
\text { temperature }\end{array}$ & $\begin{array}{r}\text { Total } \\
\text { precipitation }\end{array}$ & Elevation & Slope \\
\hline \multirow[t]{8}{*}{ Soil } & Arenosols & 71 & 36.9188 & 8.0129 & 0.1320 & 0.1115 & 0.4624 & -0.0808 & -0.6201 \\
\hline & Calcisols & 186 & 67.7720 & 8.0194 & 0.0123 & -0.6355 & 0.4861 & 0.3360 & 0.3494 \\
\hline & Cambisols & 238 & 41.4895 & 12.9810 & $0.9550 *$ & -0.4089 & -0.2570 & -0.8775 & -0.0372 \\
\hline & Fluvisols & 73 & 56.6057 & 30.4507 & 0.4650 & $-0.8291^{*}$ & -0.3751 & -0.7219 & -0.5153 \\
\hline & Leptosols & 337 & 37.6295 & 15.61437 & -0.4220 & -0.699372 & -0.6166 & -0.1992 & -0.5535 \\
\hline & Luvisols & 144 & 50.7031 & 26.9051 & $0.8249 *$ & -0.5144 & 0.8041 & -0.4060 & 0.6917 \\
\hline & Regosols & 329 & 42.5729 & 22.5279 & -0.6058 & -0.0881 & -0.0622 & 0.2386 & -0.1990 \\
\hline & Vertisols & 78 & 60.8834 & 10.4383 & 0.6370 & 0.9060 & -0.9111 & $-0.9511^{*}$ & 0.0175 \\
\hline \multirow[t]{6}{*}{ Land use } & "Arable land" & 331 & 55.1962 & 12.13281 & -0.0345 & -0.0394 & 0.1300 & 0.0387 & -0.0900 \\
\hline & "Forest" & 470 & 45.2115 & 14.2694 & -0.4833 & $-0.8794 * *$ & $0.7908^{*}$ & 0.6795 & -0.0399 \\
\hline & $\begin{array}{l}\text { "Heterogeneous } \\
\text { agricultural areas" }\end{array}$ & 169 & 48.0900 & 21.4989 & $0.9319 * * *$ & -0.5134 & $-0.7454 *$ & $-0.8818 * *$ & -0.1654 \\
\hline & $\begin{array}{l}\text { "Open spaces with little } \\
\text { or no vegetation" }\end{array}$ & 8 & 16.9625 & 11.4580 & -0.0078 & -0.8816 & -0.8009 & -0.6594 & -0.6894 \\
\hline & "Permanent crops" & 191 & 43.1218 & 19.0391 & -0.4130 & 0.5452 & -0.3750 & 0.0440 & -0.6657 \\
\hline & $\begin{array}{l}\text { "Scrub and/or herbaceous } \\
\text { vegetation associations" }\end{array}$ & 298 & 55.2321 & 21.8231 & -0.2346 & -0.0902 & 0.4386 & 0.2303 & 0.5722 \\
\hline All groups & & 1456 & 47.9880 & 21.4769 & 0.1279 & -0.2610 & -0.0530 & -0.2274 & $-0.2900^{*}$ \\
\hline
\end{tabular}

are above those calculated by Rodríguez-Murillo (2001) and Batjes (2006), who estimated SOCCs of $22.2 \mathrm{Mg} \mathrm{Cha}^{-1}$ in Spain and $20.0 \mathrm{MgC} \mathrm{ha}^{-1}$ in Jordan, respectively. Nevertheless, calculations for SOC stocks estimated for Arenosols in this research are similar to values reported in France by Arrouays et al. (2001) which range between $28 \mathrm{MgCha}^{-1}$ under "arable land" to $44 \mathrm{Mg} \mathrm{Cha}^{-1}$ under "forest".

Cambisols are the most predominant soil type in the study area together with Regosols (Table 2). Cambisols are spread in a wide range of environments around the world and under all types of vegetation. Most of the European Regosols are found in the Mediterranean region and are particularly common in arid areas. In the study area of this research, both soil types are used for agriculture and show high values of SOCCs under agricultural land uses.

We obtained lower SOCCs for Cambisols than those estimated by other authors in other Mediterranean areas such as Spain and Tunisia. In these areas, Rodríguez-Murillo (2001) and Brahim et al. (2010) calculations were $71.4 \mathrm{Mg} \mathrm{Cha}^{-1}$ and $101.8 \mathrm{MgC} \mathrm{ha}^{-1}$, respectively, at depth of $1 \mathrm{~m}$. Larger values were obtained in Germany $\left(114 \mathrm{MgC} \mathrm{ha}^{-1}\right)$ and Central Europe (118 Mg Cha $\left.{ }^{-1}\right)$ by Neufeldt (2005) and Batjes (2002). On the other hand, values of SOCCs for Cambisols lie between those proposed by Arrouays et al. (2001) ranging from $30 \mathrm{MgCha}^{-1}$ for "permanent crops" and $121 \mathrm{Mg} \mathrm{Cha}^{-1}$ for moors and heathlands. Moreover, Batjes (2006) found similar estimations in Jordan for Cambisols, with values of $23 \mathrm{MgCha}^{-1}$ at $0.3 \mathrm{~m}$ depth and $45 \mathrm{MgCha}^{-1}$ at $1 \mathrm{~m}$ depth.
Soil organic C content for Regosols in this study is larger than values reported by other authors in Spain and other Mediterranean regions. Rodríguez-Murillo estimated $48.7 \mathrm{Mg} \mathrm{Cha}^{-1}$ and Díaz-Hernández et al. (2003) obtained $35 \mathrm{Mg} \mathrm{Cha}^{-1}$ at $0.5 \mathrm{~cm}$ depth and $52 \mathrm{MgCha}^{-1}$ at $1 \mathrm{~m}$ depth and in Jordan, Batjes (2006) reported $8 \mathrm{MgCha}^{-1}$. Compared to France, SOCCs of Regosols under "forest" are similar, around $50 \mathrm{MgC} \mathrm{ha}^{-1}$ (Arrouays et al., 2001) but we estimated larger values under "permanent crops".

We found similar SOCCs in Luvisols and Fluvisols, although larger values for Fluvisols were encountered under agricultural uses opposite to Luvisols which presented higher SOCCs under "forest" and scrubs. The highest values among all soil classes and land use types in this study were those obtained for Fluvisols under "maritime wetlands" $\left(107.64 \mathrm{Mg} \mathrm{Cha}^{-1}\right)$ at $1 \mathrm{~m}$ depth. Fluvisols are fertile soils and frequently occur under rice crops in wetlands. Most of the area covered by Luvisols, which have a great potential for a large number of crops when drainage is adequate, is under "permanent crops" and "arable land". RodríguezMurillo (2001) reported higher values for both Fluvisols and Luvisols in Spain, $75.8 \mathrm{MgCha}^{-1}$ and $66 \mathrm{MgCha}^{-1}$, respectively, nonetheless our estimations are within the values propose in France (Arrouays et al., 2001). They estimated SOCCs ranging from $27 \mathrm{MgCha}^{-1}$ under "permanent crops" to $102 \mathrm{Mg} \mathrm{Cha}^{-1}$ under Pastures for Fluvisols and $29 \mathrm{MgC} \mathrm{ha}^{-1} \mathrm{MgCha}^{-1}$ under "permanent crops" to $84 \mathrm{Mg} \mathrm{Cha}^{-1}$ under Pastures.

Planosols and Solonchaks occupy 1916.20 and $1481.70 \mathrm{~km}^{2}$, respectively, mostly under "arable land". 
Planosols are frequently used for grazing, nevertheless, under specific management they can be used for cultivation. Solonchaks are widespread in the arid and semi-arid climatic zones and land uses are limited by the salt content. Thus, in the study area low values are found under "arable land" and relatively large under "maritime wetlands" (15.85 Mg Cha ${ }^{-1}$ and 70.80 $\mathrm{Mg} \mathrm{Cha}^{-1}$, respectively). These results are in agreement with those estimated in Spain by Rodríguez-Murillo (2001), with $76.3 \mathrm{Mg} \mathrm{Cha}^{-1}$.

Generally, SOC contents are larger in the surface layer declining with depth. This is in agreement with previous studies (e.g. Batjes, 1996; Salome et al., 2010). In arid soils from SE Spain, for example, Albadalejo et al. (2011) found that SOC from different soil types showed significant variations within the first $30 \mathrm{~cm}$, and suggested that these variations were caused mainly by land use and precipitation. Nevertheless, the distribution of SOC with depth is likely to vary with different soil types (Schrumpf et al., 2008). More than $50 \%$ of the organic $\mathrm{C}$ of all studied soil groups was stored in subsoil horizons $(0-25 \mathrm{~cm})$, the layer more susceptible to change upon land use change especially agricultural and "forest" management. These results are in line with Schöning et al. (2006) and Grüneberg et al. (2010). In particular, Leptosols, which are commonly shallow soils with limited soil development, accumulate $83.9 \%$ in the first $0.25 \mathrm{~m}$ (with $97.4 \%$ of the SOC content in the first $0.5 \mathrm{~m}$ ). Most of the Leptosols are under scrub and/or herbaceous associations and "forest", and SOCCs obtained in this research for Leptosols were lower than values reported by other areas in similar regions (Rodríguez-Murillo, 2001; Batjes, 2006). SOCC under "forest" is below other land uses with similar areas, as "arable land" or "permanent crops". This may be explained as a consequence of the low degree of development of forest soils, where Cambisols, Leptosols and Regosols are dominant. Leptosols under "forest", for example, occupy an area 6.9 and 3.2 times larger than under "arable land" and "permanent crops", respectively.

\subsection{Relationship between SOCC and environmental variables}

It is critical to determine the different factors explaining SOC stocks at different scales (Dai and Huang, 2006; Rodeghiero et al., 2010). According to Jenny (1941), climate is the main factor that influences the soil organic matter content through its effect on inputs (related to biomass production) and outputs produced by the microbial metabolism (influenced in turn by the climate and water availability). Natural or anthropic processes favouring increased biomass production (such as soil fertility, photosynthetic efficiency, fertilisation, etc.) should be favourable to the decrease in atmospheric $\mathrm{C}$ content, by fixation in biomass or in soil (Macías et al., 2004).

The correlation between SOC content and winter temperature was positive for most soil types, although significant cor- relation coefficients were only observed for Cambisols and Luvisols. Correlation coefficients between SOC content and summer temperature were mostly negative, but significant correlations were only observed for Fluvisols. Other authors have reported negative correlations between temperature and SOC content (Hontoria et al., 1999; Ganuza and Almendros 2003; Dai and Huang, 2006). Concentrations of organic C are usually higher in cold environments, where decomposition rates are low (Paustian, 2002). However, the range of temperatures in the studied area is not as wide as those observed in broad scale studies (e.g. Dai and Huang, 2006), and local processes can be significant. Our results suggest that extremely low winter and extremely high summer mean temperatures in the study area contribute to a decrease in SOC content.

Significant correlation coefficients were observed for precipitation and SOC content from "forest" $(r=0.7908)$ and "heterogeneous agricultural areas" $(r=-0.7454)$, but contradictory results exist and a clear trend was not observed. Weak and no significant correlation was found when all soil profiles were considered. This is in contrast with results from other authors in Spain (Hontoria et al., 1999; RodríguezMurillo, 2001). Hontoria et al. (1999) obtained $r=0.55$ for the whole country and Ganuza and Almendros (2003) estimated $r=0.5675$ in the Basque Country (North Spain). Jobággy and Jackson (2000) analysed a large amount of soil profiles in the United States and elsewhere reporting values of $r=0.5$ for $1 \mathrm{~m}$ depth. In a recent research, Ruiz Sinoga et al. (2012) have found that SOC sequestration in Mediterranean rangelands from southern Spain is reduced one order of magnitude from soil profiles under humid $\left(59.9 \mathrm{Mg} \mathrm{ha}^{-1}\right)$ to semiarid (11.6 $\left.\mathrm{Mg} \mathrm{ha}^{-1}\right)$ climatic conditions.

High and significant negative correlations were observed between SOC content and elevation for Vertisols. Also, high (but non-significant) correlations were observed for Cambisols $(r=-0.8775)$ and Fluvisols $(r=-0.7219)$. Other soils showed weak and non-significant correlations. For LU types, elevation was significantly correlated to SOC content only in "heterogeneous agricultural areas". When all groups were considered, weak and no significant correlations were observed between SOC and elevation, in contrast with other studies by Hontoria et al. (1999) and RodríguezMurillo (2001), although these authors considered soil data from the Iberian Peninsula.

\subsection{Limitations of the methodology}

It is known that soil properties have a high spatial variability and, according to many authors, organic $\mathrm{C}$ is one of the soil parameters with the highest variability (Hontoria et al., 1999; Schrumpf et al., 2008; Don et al., 2009). We found relatively high CV among groups, particularly large in natural land uses such as forest and scrub, which is in accordance with many authors. Batjes (2006) obtained CVs over $150 \%$ for some soil groups in Central Europe and even larger values in his study of the total C in the soils of the world (Batjes, 1996). In 
Spain, for example, Rodríguez-Murillo (2001) reported CVs between 49.3 and $136.0 \%$ for SOC concentrations under the main land use types. Relatively high $\mathrm{CV}$ are usual for regional or national scale studies and the IPCC assume that there are uncertainties on absolute stock values calculations and therefore high quality data sets should be used to reduce estimation uncertainty. It is necessary to assume some uncertainty when using average values with high $\mathrm{CV}$ in small scale studies (as in national or regional inventories).

All soil types are not homogenously distributed. Cambisols, Fluvisols, Leptosols, Luvisols, Regosols, and Vertisols account for $93.29 \%$ of the study area, whereas Arenosols, Calcisols, Planosols and Solonchaks correspond to $6.71 \%$. Consequently, when these soils are subdivided per LU class, the number of soil profiles per soil-LU combination is sometimes low. However, these combinations are representative of small areas which do not alter significantly global estimations.

Many empirical models have been proposed for explaining the relationship between SOC content and climatic factors. Global data show that organic $\mathrm{C}$ content increases in soils under high rainfall and low temperature (Oades, 1988). At detailed scales, anthropic transformation of ecosystems may strongly affect SOC content. Intensification of agricultural management, silviculture or afforestation, for example, may buffer the impact of climate on SOC. As a consequence, regional or local-scale studies may not show strong dependence between SOC content and climatic variables. Also, in the context of global change, other SOC redistribution or sequestration processes might be considered, as the increasing frequency of wildfires. At wide scale, wildfires are assumed to increase the organic $\mathrm{C}$ stock in soils, as reported by González-Pérez et al. (2004). At local scale, redistribution processes of soil organic matter by water erosion processes following wildfires may be substantial. It has been reported that erosion and the subsequent deposition after forest fires constitute a sink for C-rich sediments at the valley bottoms. In addition, $\mathrm{C}$ losses by soil erosion at the hillslopes may be replaced by the production of new biomass (Novara et al., 2011).

\section{Conclusions}

This study comprises the first comprehensive analysis of current organic C stocks for each soil type under present land use types in Andalusia, Southern Spain. In this research soil organic $\mathrm{C}$ pools and their distribution within the soil profile, are estimated under existing land uses, providing baseline information to assess the potential of the different soil types for SOC sequestration.

Soil organic C stocks are estimated at different depths $(0$ $25,25-50$ and $50-75 \mathrm{~cm}$ ) under different land use/soil type associations. Cambisols and Regosols are the most common soil types in Andalusia, but Calcisols and Vertisols show the highest SOCC values, above $65 \mathrm{MgCha}^{-1}$. In total, SOC stock is $415 \mathrm{Tg}$ in the upper $75 \mathrm{~cm}$ and on average, with $55 \%$ stored in the first layer $(0-25 \mathrm{~cm})$. The amount of SOC in the first $75 \mathrm{~cm}$ was significantly correlated with annual mean temperature, annual mean precipitation and elevation in natural areas.

Regional studies for assessing soil organic $\mathrm{C}$ stocks are needed and should include information about LU/LC and soil class.

Nevertheless, large uncertainties in estimates of SOC stock prevail. These uncertainties can be also attributed to gaps in our understanding of both future land $\mathrm{C}$ content and quantification of the response of $\mathrm{C}$ sequestration according to land use change. Therefore, the role of future land use change in $\mathrm{C}$ stocks is considered in further research.

Acknowledgements. This research has been partly funded by the Ministry of Economy, Innovation and Science (Research Project 851238) and the Regional Ministry of Environment (Research Project 0501/0268) of the Andalusian Government. Ozren Bogdanović (Andalusian Centre of Developmental Biology, CABD) proofread a previous version of the manuscript.

Edited by: A. Cerdà

\section{References}

Albadalejo, J., Martínez-Mena, M., García Franco, N., Almagro, M., and Ortiz Silla, R.: Sensibilidad del carbono orgánico del suelo al cambio global: influencia de la profundidad, in: Control de la degradación y uso sostenible del suelo, edited by: Ortiz Silla, A. and Sánchez Navarro, A., University of Murcia, Murcia, 577-580, 2011.

Anaya-Romero, M., Pino, R., Moreira, J. M., Muñoz-Rojas, M., and de la Rosa, D.: Analysis of soil capability versus land use change by using CORINE land cover and MicroLEIS, Int. Agrophys., 25, 395-398, 2011.

Arrouays, D., Deslais, W., and Badeau, V.: The carbon content of topsoil and its geographical distribution in France, Soil Use Manage., 17, 7-11, 2001.

Bahn, M., Kutsch, W. L., Heinemeyer, A.: Synthesis: emerging issues and challenges for an integrated understanding of soil carbon fluxes, in: Soil Carbon Dynamics, An Integrated Methodology, edited by: Kutsch, W. L., Bahn, M., and Heinemeyer, A., Cambridge, Universty Press Cambridge, 257-271, 2009.

Batjes, N. H.: Total carbon and nitrogen in the soils of the world, Eur. J. Soil Sci., 47, 151-163, 1996.

Batjes, N. H.: Carbon and nitrogen stocks in the soils of Central and Eastern Europe, Soil Use Manage., 18, 324-329, 2002.

Batjes, N. H.: Organic carbon stocks in the soils of Brazil, Soil Use Manage. 21, 22-24, 2005.

Batjes N. H.: Soil carbon stocks of Jordan and projected changes upon improved management of croplands, Geoderma, 132, 361371, 2006.

Batjes, N. H. and Dijkshoorn, J. A.: Carbon and nitrogen stocks in the soils of Amazon Region, Geoderma, 89, 273-286, 1999. 
Blake, G. R. and Hartge, K. H.: Bulk density, in: Methods of Soil Analysis-Part 1, Physical and Mineralogical Methods, 2nd edn., edited by: Klute, A., American Society of Agronomy, Madison, 1986.

Blondel, J. and Aronson, J.: Biodiversity and ecosystem function in the Mediterranean basin: human and non-human determinants, in: Mediterranean-Type Ecosystems, edited by: Davis, G. W. and Richardson, D. M., Springer, New York, 42-20, 1995.

Boix-Fayos, C., de Vente, J., Albaladejo, J., and Martínez-Mena, M.: Soil carbon erosion and stock as affected by land use changes at the catchment scale in Mediterranean ecosystems, Agr. Ecosyst. Environ., 133, 75-85, 2009.

Bradley, R. I., Milne, R., Bell, J., Lilly, A., Jordan, C., and Higgins, A.: A soil carbon and land use database for the United Kingdom, Soil Use Manage., 21, 363-369, 2005.

Brahim, N., Bernoux, M., Blavet, D., and Gallali, T.: Tunisian soil organic carbon stocks, Int. J. Soil Sci., 5, 34-40, 2010.

CSIC-IARA: Mapa de suelos de Andalucía, Instituto Andaluz de la Reforma Agraria (Junta de Andalucía), Sevilla, Consejo Superior de Investigaciones Científicas, Madrid, 1989.

Dai, W. and Huang, Y.: Relation of soil organic matter concentration to climate and altitude in zonal soils of China, Catena, 65, 87-94, 2006.

De la Rosa, D., Mayol, F., Moreno, F., Cabrera, F., Diaz-Pereira, E., and Antoine, J.: A multilingual soil profile database (SDBm Plus) as an essential part of land resources information systems, Environ. Modell. Softw., 17, 721-730, 2002.

De la Rosa, D., Mayol, F., Diaz-Pereira, E., Fernández M., and de la Rosa Jr, D.: A Land Evaluation Decision support System (MicroLEIS DSS) for Agricultural Soil Protection, Environ. Modell. Softw., 19, 929-942, 2004.

Díaz-Hernández, J. L., Barahona Fernádez, E., and Linares González, J.: Organic and inorganic carbon in soils of semiarid regions: a case study from the Guadix-Baza basin (Southeast Spain), Geoderma, 114, 65-80, 2003.

Don, A., Scholten T., and Schulze, E. D.: Conversion of cropland into grassland: Implications for soil organic-carbon stocks in two soils with different texture, J. Plant Nutr. Soil Sci., 172, 53-62, 2009.

ESRI: ArcGIS, 9.2., Environmental Scientific Research Institute, Redlands, CA, 2006.

Eswaran, H., Van der Berg, E., and Reich, P.: Organic carbon in soils of the world, Soil Sci. Soc. Am. J., 57, 192-194, 1993.

FAO: Guidelines for soil description, 4th edition, Food and Agriculture Organization of the United Nations, Rome, 2006.

Flores, M. V., Ferrer, F., Jiménez, G., Valera, A., and Goberna, M.: Distribución del contenido de carbono orgánico en los suelos del norte de Castellón, in: Control de la degradación de suelos y la desertificación, edited by: Rodríguez Rodríguez, A. and Arbeló, C. D., University of La Laguna, La Laguna, 207-208, 2007.

Ganuza, A. and Almendros, G.: Organic carbon storage in soils of representative ecosystems in the Basque Country (Northern Spain) as related to climate, vegetation type and edaphic variables, Biol. Fert. Soils, 37, 154-162, 2003.

Gibson, T. S., Chan, K. Y., Sharma, G., and Shearman, R.: Soil carbon sequestration utilising recycled organics. A review of the scientific literature, Project 00/01R-3.2.6A.2002, Organic Waste Recycling Unit, NSW Agriculture, NSW Agriculture, Sydney, 2002.
González-Pérez, J., González-Vila, F. J., Almendros, G., and Knicker, H.: The effect of fire on soil organic matter - a review, Environ. Int., 30, 855-870, 2004.

Grüneberg, E., Schöning, I., Kalko, E. K. V., and Weisser, W. W.: Regional organic carbon stock variability: A comparison between depth increments and soil horizons, Geoderma, 155, 426433, 2010.

Heymann, Y., Steenmans, Ch., Croissille, G., and Bossard, M.: Corine Land Cover technical guide, Office for Official Publications of the European Communities, Luxembourg, 1994.

Hontoria, C., Rodríguez-Murillo, J. C., and Saa, A.: Relationships between soil organic carbon and site characteristics in peninsular Spain, Soil Sci. Soc. Am. J., 63, 617-621, 1999.

Houghton, R. A.: The contemporary carbon cycle, in: Biogeochemistry, edited by: Schlesinger, W. H., Elsevier-Pergamon, Oxford, 473-513, 2005.

Howard, P. J. A., Loveland, P. J., Bradley, R. I., Dry, F. T., Howard, D. M., and Howard, D. C.: The carbon content of soil and its geographical distribution in Great Britain, Soil Use Manage., 11, 9-15, 1995.

Ibáñez, J. J., Sánchez, J., de Alba, S., López, M., and Boixadera, J.: Collection of soil information in Spain: a review, in: Soil resources of Europe: 2nd ESB Research Report No. 9, edited by: Jones, R. J. A., Houskova, B., Bullock, P., and Montanarella, L., Luxembourg, Office for Official Publications of the European Communities, 2005.

ICA: Modelo Digital de Elevaciones, 100 m, CD-ROM: Instituto de Cartografía de Andalucía, Consejería de Obras Públicas y Transportes (Junta de Andalucía), Sevilla, 1999.

IPCC: Special report on emissions scenarios - a special report of working group III of the Intergovernmental Panel on Climate Change, Cambridge University Press, Cambridge, 2000.

IPCC: Climate Change 2007, The Physical Science Basis, Cambridge University Press, Cambridge/New York, 2007.

IUSS Working Group WRB: World reference base for soil resources 2006, World Soil Resources Reports No. 103, Food and Agriculture Organization of the United Nations, Rome, 2006.

Jenny, H.: Factors of soil formation: a system of quantitative pedology, Mc Graw-Hill, London, 1941.

Jobbágy, E. G. and Jackson, R. B.: The vertical distribution of soil organic carbon and its relation to climate and vegetation, Ecol. Appl., 104, 423-436, 2000.

Jordán, A. and Zavala, L. M.: Obtención de Indicadores a partir de la Base de Perfiles de Suelo para su aplicación a la Modelización Climática, Technical report 0501/0268, Consejería de Medio Ambiente (Junta de Andalucía), Sevilla, 2009.

Jordán López, A., Martínez-Zavala, L., and Bellinfante Crocci, N.: Reserva de Carbono en Suelos Forestales Mediterráneos, in: Tendencias Actuales de la Ciencia del Suelo, edited by: Bellinfante, N. and Jordán, A., Universidad de Sevilla, 638-647, 2007.

Lal, R.: Global potential of soil $\mathrm{C}$ sequestration to mitigate the greenhouse effect, Crc. Cr. Rev. Plant Sci., 22, 151-184, 2003.

Lal, R.: Soil carbon sequestration to mitigate climate change, Geoderma, 123, 1-22, 2004.

Leifeld, J., Bassin, S., and Fuhrer, J.: Carbon stocks in Swiss agricultural soils predicted by land-use, soil characteristics, and altitude, Agr. Ecosyst. Environ., 105, 255-266, 2005.

Lettens, S., Van Orshoven, J., Van Wesemael, B., De Vos, B., and Muys, B.: Stocks and fluxes of soil organic carbon for landscape 
units in Belgium derived from heterogeneous data sets for 1990 and 2000, Geoderma, 127, 11-23, 2005.

Liebens, J. and VanMolle, M.: Influence of estimation procedure on soil organic carbon stock assessment in Flanders, Belgium, Soil Use Manage., 19, 364-371, 2003.

Liski, J., Perruchoud, D., and Karjalainen, T.: Increasing carbon stocks in the forest soils of western EUROPE, Forest Ecol. Manag., 169, 159-175, 2002.

Macías, F., Calvo de Anta, R., Rodríguez Lado, L., Verde, R., Pena Pérez, X., and Camps Arbestain, M.: El sumidero de carbono de los suelos de Galicia, Edafología, 11, 341-376, 2004.

MARM: Inventario de emisiones de gases de efecto invernadero de España e información adicional, años 1990-2009, Comunicación a la secretaría del convenio marco sobre cambio climático y Protocolo de Kioto, Ministerio de Medio Ambiente, Medio Rural y Marino, Madrid, 2011.

Martin, M. P., Wattenbach, M., Smith, P., Meersmans, J., Jolivet, C., Boulonne, L., and Arrouays, D.: Spatial distribution of soil organic carbon stocks in France, Biogeosciences, 8, 1053-1065, doi:10.5194/bg-8-1053-2011, 2011.

Meersmans, J., De Ridder, F., Canters, F., De Baets, S., and Van Molle, M.: A multiple regression approach to assess the spatial distribution of soil organic carbon (SOC) at the regional scale (Flanders, Belgium), Geoderma, 143, 1-13, 2008.

Moreira, J. M.: Mapas de usos y coberturas vegetales del suelo de Andalucía, Escala 1/25,000, Guía Técnica, Consejería de Medio Ambiente (Junta de Andalucía), Sevilla, 2007.

Morisada, K., Ono, K., and Kanomata, H.: Organic carbon stock in forest soils in Japan, Geoderma, 119, 21-32, 2004.

Muñoz-Rojas, M., De la Rosa, D., Zavala, L. M., Jordán, A., and Anaya-Romero M.: Changes in land cover and vegetation carbon stocks in Andalusia, Southern Spain (1956-2007), Sci. Total Environ., 409, 2796-2806, 2011.

Neufeldt, H.: Carbon stocks and sequestration potentials of agricultural soils in the federal state of Baden-Württemberg, SW Germany, J. Plant Nutr. Soil Sci., 168, 202-211, 2005.

Novara, A., Gristina, L., Bodì, M. B., and Cerdà, A.: The impact of fire on redistribution of soil organic matter on a Mediterranean hillslope under maquia vegetation type, Land Degrad. Dev., 22, 530-536, 2011

Oades, J. M.: The retention of organic matter in soils, Biogeochemistry, 5, 35-70, 1988.

Ostle, N. J., Levy, P. B., Evans, C. D., and Smith, P.: UK land use and soil carbon sequestration, Land Use Policy, 26, 274-283, 2009.

Paustian, K.: Organic matter and global cycle, in: Encyclopedia of Soil Science, edited by: Lal, R., Marcel Dekker Inc., NY, 895898,2002
Phachomphon, K., Dlamini, P., and Chaplot, V.: Estimating carbon stocks at a regional level using soil information and easily accessible auxiliary variables, Geoderma, 155, 372-380, 2010.

Rodeghiero, M., Tonolli, S., Vescovo, L., Gianelle, D., Cescatti, A., and Sottocornola, M.: INFOCARB: a regional scale forest carbon inventory (Provincia Autonoma di Trento, Southern Italian Alps), Forest Ecol. Manag., 259, 1093-1101, 2010.

Rodríguez-Murillo, J. C.: Organic carbon content under different types of land use and soil in peninsular Spain, Biol. Fert. Soils, 33, 53-61, 2001.

Ruiz Sinoga, J. D., Pariente, S., Romero Diaz, A., and Martinez Murillo, J. F.: Variability of relationships between soil organic carbon and some soil properties in Mediterranean rangelands under different climatic conditions (South of Spain), Catena, 94, 17-25, 2012.

Salome, C., Nunan, N., Pouteau, V., Lerch, T. Z., and Chenu, C.: Carbon dynamics in topsoil and in subsoil may be controlated by different regulatory mechanisms, Glob. Change Biol., 16, 416426, 2010.

Schöning, I., Totsche, K. U., and Kögel-Knabner, I.: Small scale spatial variability of organic carbon stocks in litter and solum of a forested Luvisol, Geoderma, 136, 631-642, 2006.

Schrumpf, M., Schumacher, J., Schöning, I., and Schulze, E. D.: Monitoring carbon stock changes in European soils: process understanding and sampling strategies, in: The Continental-Scale Greenhouse Gas Balance of Europe, edited by: Dolman, A. J., Freibauer, A., and Valentini, R., Springer, NY, 2008.

Schulp, C. J. E, Nabuurs, G. J., and Verburg, P. H.: Future carbon sequestration in Europe-Effects of land use change, Agr. Ecosyst. Environ., 127, 251-264, 2008.

Schwartz, D. and Namri, M.: Mapping the total organic carbon in the soils of the Congo, Global Planet. Change, 33, 77-93, 2002.

Smith, P.: Carbon sequestration in croplands: the potential in Europe and the global context, Eur. J. Agron., 20, 229-236, 2004.

Smith, P.: Land use change and soil organic carbon dynamics, Nutr. Cycl. Agroecosys., 81, 169-178, 2008.

SPSS: PASW Statistics 18.0. SPSS, Inc., Chicago, 2009.

StatSoft: STATISTICA (data analysis software system), version 6 Statsoft, Inc., Tulsa, 2001

VandenBygaart, A. J.: Monitoring soil organic carbon stock changes in agricultural landscapes: issues and a proposed approach, Can J. Soil Sci., 86, 451-463, 2006.

Walkley, A. and Black, I. A.: An examination of the Degtjareff method for determining soil O. M. and a proposed modification of the chromic acid titration method, Soil Sci., 37, 29-38, 1934. 